\title{
Epidemiologic surveillance of canine visceral leishmaniasis in the municipality of Recife, Pernambuco
}

\author{
Vigilância epidemiológica de leishmaniose visceral canina \\ no município de Recife, Pernambuco
}

\author{
Filipe Dantas-Torres ${ }^{1}$, Maria Aparecida da Gloria Faustino ${ }^{2}$, \\ Osmar Cavalcanti da Costa Lima ${ }^{3}$ and Ridelane Veiga Acioli ${ }^{3}$
}

\begin{abstract}
This paper describes an epidemiologic investigation carried out in Imbiribeira district, where a canine visceral leishmaniasis case was recorded. Despite the absence of seropositive dogs and sand flies, these findings are not sufficient to discard the occurrence of a zoonotic cycle of visceral leishmaniasis in Recife.
\end{abstract}

Key-words: Visceral leishmaniasis. Epidemiology. Pernambuco. Brazil.

\section{RESUMO}

Este artigo descreve uma investigação epidemiológica realizada no bairro da Imbiribeira, onde fora registrado um caso de leishmaniose visceral canina. Apesar da ausência de cães soropositivos e de flebotomíneos, esses achados não são suficientes para descartar a ocorrência do ciclo zoonótico da leishmaniose visceral em Recife.

Palavras-chaves: Leishmaniose visceral. Epidemiologia. Pernambuco. Brasil.

Historically, visceral leishmaniasis has been considered endemic in Pernambuco State. However, some municipalities, e.g. Recife, are considered free of autochthonous cases ${ }^{4}$. Nevertheless, in 2002, a dog from the district of Imbiribeira was observed with clinical signs of visceral leishmaniasis and infection by Leishmania amastigotes was confirmed. This case of canine visceral leishmaniasis was reported as autochthonous of Recife ${ }^{3}$. Consequently, we conducted an epidemiologic investigation in Imbiribeira to determine the presence of seropositive dogs or phlebotomine sand flies. The objective of this paper was to present the results of this investigation.

As recommended by the Brazilian Ministry of Health ${ }^{6}$, serologic screening for anti-Leishmania-specific antibodies was performed in all dogs found in a radius of 200 meters from the house where the previous case was notified. From October 2003 to February 2004, total blood of 85 dogs (domestic and stray dogs) of various breeds, ages and both sexes, was collected in filter paper and processed by indirectimmunofluorescence assay (IFA) at the Central Laboratory of the Health Secretary of Pernambuco State. A cut-off point of 1:40 was adopted.
During the last four months of the study, CDC light traps were set one meter above the ground, inside and outside of the houses, from 6:00 pm to 6:00 am. Each week, six houses were randomly selected at random and two collections were performed for each house, totaling thirty 12-hour collections. The traps were sent to the Environmental Surveillance Center of Recife, for processing and identification of the captured specimens, using appropriate keys $^{27}$.

There were no reactive blood samples, which confirms the absence of antibodies against Leishmania parasites in the screened dogs. Likewise, no infected sand flies were found and all flies collected belonged to the genus Culex or Aedes.

Prior to this study, a canine serologic survey had been carried out in several districts of Recife. The authors analyzed sera from 623 dogs (both domestic and stray dogs) but only two stray dogs presented titer values higher than 1:40 in IFA. However, it is a well-known fact that the use of IFA may decrease the effectiveness of Brazilian visceral leishmaniasis control programs by failure to sacrifice false-negative dogs ${ }^{1}$.

In Recife, there is only one description of a male Lutzomyia longipalpis, which was recorded approximately

1. Centro de Pesquisas Aggeu Magalhães, Fundação Oswaldo Cruz, Recife, PE e Bolsista de Mestrado do CNPq. 2. Universidade Federal Rural de Pernambuco, Recife PE. 3. Centro de Vigilância Ambiental do Recife, Recife, PE.

Address to: Dr. Filipe Dantas Torres. CPqAm/FIOCRUZ, Campus UFPE, Av Moraes Rego s/n, 50670-420 Recife, PE, Brasil.

Tel: 5581 2101-2562, Fax: 5581 3453-2449.

e-mail: fdt@ cpqam.fiocruz.br

Recebido para publicação em 28/7/2004

Aceito em 6/6/2005 
twenty-eight years ago ${ }^{7}$. Due to this fact, Recife has been classified as not receptive, but vulnerable due to the frequent migration of dogs from enzootic areas. Hence, the case of canine visceral leishmaniasis previously described in Imbiribeira is probably a case imported from another district and possibly even from another municipality of Pernambuco.

In fact, our results point to the nonexistence of Leishmania (Leishmania) chagasi ( = L infantum) in the studied region, though these findings are not sufficient to definitively exclude this possibility. Thus, epidemiologic surveillance must be maintained. In the same manner, further entomologic studies into the local phlebotomine fauna should be encouraged in order to identify any change in the local epidemiology, which may be seen as a major challenge for public health authorities in Recife.

\section{ACKNOWLEDGEMENTS}

We thank the referee for his suggestions and helpful comments.

\section{REFERENCES}

1. Alves WA, Bevilacqua PD. Reflexões sobre a qualidade do diagnóstico da leishmaniose visceral canina em inquéritos epidemiológicos: 0 caso da epidemia de Belo Horizonte, Minas Gerais, Brasil, 1993-1997. Cadernos de Saúde Pública 20: 259-265, 2004.

2. Balbino VQ, Andrade PP, Luna LKS. Identificação de flebotomíneos de importância médica do Estado de Pernambuco. Universidade Federal de Pernambuco, Recife, 2003.

3. Cavalcanti MP, Morais SRC, Faustino MAF, Alves LC, Almeida MAO, Azevedo JPS, Ferreira Júnior RJ. Ocorrência de leishmaniose visceral canina na cidade do Recife. In: Resumos do XII Congresso Brasileiro de Parasitologia Veterinária, Rio de Janeiro, 1 CD-ROM, 2002.

4. Dantas-Torres F, Brandão-Filho SP. Distribuição espacial da leishmaniose visceral no estado de Pernambuco, nordeste do Brasil. Revista da Sociedade Brasileira de Medicina Tropical 38 ( supl I) : 411-412, 2005.

5. Lima Júnior AD, Alves LC, Savani Mouriz ESM, Nicoletti Dáuria, MCGO, Balduino SA. A survey of canine visceral leishmaniasis in the city of Recife, Northeastern Brazil. In: Proceedings of the $45^{\text {th }}$ Annual Meeting, Salt Lake City, 2000.

6. Ministério da Saúde. Controle, diagnostico e tratamento da leishmaniose visceral ( calazar): normas técnicas. Ministério da Saúde, Brasília, 1996.

7. Oliveira MHC, Lucena DT, Leal MCA, Nascimento AMLC. Flebotomíneos gênero Lutzomyia França, 1924 da região metropolitana no Recife (Diptera - Psychodidae). Anais da Universidade Federal Rural Pernambuco 2/3: 45-82, 1977/1978. 